\title{
Hajdú Dávid
}

\section{A munkanélküliség és felnőttképzés területi eloszlása az Észak-magyarországi régióban}

Jelen tanulmány az Észak-magyarországi régióban található megyék munkanélküliségi problémáinak és felnőttképzési aktivitásának területi különbségeit vizsgálja. Szeretnék rámutatni arra, hogy a területileg és szakmailag jól megszervezett felnőttképzés hatékony munkaeröpiaci eszköznek minösülhet. Kutatásomat szekunder adatbázisok feldolgozásával végeztem el, a vizsgálatok középpontjába a régió három megyéje között mutatkozó eltéréseket helyeztem. Borsod-Abaúj-Zemplén megye mind a támogatottság, mind a felnöttképzésben résztvevők száma alapján a legmagasabb mutatószámokkal rendelkezik. Nógrád megye rendelkezik a legmagasabb önköltséges részvételi aránnyal, ez alapján fontos lenne a megyében támogatott képzéseket is nagyobb számban indítani, hisz a tanulni akarás kimutatható a megyében. Heves megyében a kedvezöbb munkaerőpiaci folyamatok miatt kevésbé érzékelhetö a támogatott képzések hiánya. Az Európai Unió által támogatott képzések nagyobb részét tréningek, kompetencia képzések és általános felnöttképzések jelentik, amelyek számos kompetencia elsajátításához hozzájárulnak, azonban munkaeröpiaci potenciálja és gazdasági hatása nagy mértékben nincs. Ezért inkább szakmai képzéseket kellene elötérbe helyeznie a támogatónak, hisz sokkal nagyobb eséllyel tudnak majd elhelyezkedni egy új szakmával, mint egy kompetencia fejlesztésére irányuló képzéssel. A képzéseket, legföképpen a szakmai képzéseket a vidéki helyszineken kellene oktatni, mert csökkenthetné az elvándorlást a leszakadó, rurális térségekböl.

Kulcsszavak: humán eröforrások, felnöttképzés, munkanélküliség, területi egyenlötlenség JEL-kód: I26, J24, M53

\section{https://doi.org/10.32976/stratfuz.2020.14}

\section{Irodalmi áttekintés}

A foglalkoztatottság és az életminőség szorosan koherens fogalomkör egyéni és társadalmi szinten egyaránt. A munkaerőt, mint a termelési tényezőt ugyanúgy érintik a piacgazdaság törvényi változásai. Folyamatos verseny uralkodik a munkaerőpiacon, amelyek előnyt és hátrányt is jelenthetnek. A társadalmi kohézió magában foglalja azoknak a feltételeknek a javítását, amelyek szükségesek az esélyegyenlőséghez. A hátrányok mérséklését célozza meg a foglalkoztatáspolitika, a szociálpolitika, és az oktatáspolitika a szociális kiadások, a képzési, oktatási ráfordítások és a munkaerő-piaci támogatások segítségével (Cserné et al., 2006).

A munkanélküliség jelenségét a munkaerő kínálatának a munkaerő keresletet meghaladó mértéke hívja életre. A munkanélküliség minden társadalomban jelen van valamilyen formában, azonban igen eltérő mértékben okoz problémát a különböző területegységekben (Siposné Nándori, 2016) és a településhierarchia különböző szintjein (Alpek-Tésits, 2014). A munkanélküliek köre ugyanakkor egy igen jelentős potenciális munkaerőtartalékként, a régió endogén erőforrásaként is megközelíthető (Győri-Egri, 2020). A gazdasági versenyképességet meghatározó társadalmigazdasági faktorok között kiemelt jelentőséggel bír a munkaerő képzettsége (Káposzta-Tóth, 2014). Az egész életen át tartó tanulás egyre fontosabbá válik a mai társadalomban. Az egyéneknek képzésen keresztül kell fejleszteniük készségeiket annak érdekében, hogy sikeresen beilleszkedjenek a munkaeröpiacra. Azonban a képzések között is jelentős különbségek mutatkozhatnak abból a szempontból, hogy mennyire hatékonyan segítik elö a munkaeröpiaci integrációt (Nijhof, 2005; Cedefop, 2015).

Számos tanulmány rámutatott arra, hogy az oktatás és a munka világában nyújtott teljesítmény nincs összhangban egymással (Livingstone, 2010). A szakképzés gyakran túlzottan fókuszált lehet, és nem biztos, hogy kellően felkészíti az egyéneket a munka világának egyre növekvő összetettségére. Azonban a kutatók arra is felhívták a figyelmet, hogy a formális 
oktatásban megszerzett ismereteket a szakmai gyakorlatokon belül kell elhelyezni vagy kontextusba kell helyezni (Nilsson, 2010). Az oktatás és a munka közötti szakadék áthidalása során figyelembe kell venni mind a kínálati, mind a keresleti oldalt, és azokat a folyamatokat, amelyekben a munkavállalók kompetenciája illeszkedik a munkahelyek követelményeihez. A szakmai és szakképzés fontos abban, hogy az embereket a munkaerőpiacon és a társadalomban el tudjuk helyezni. A felnőttképzésben egyre hangsúlyosabb a munkaerőpiacra való felkészítés jelentősége, amelynek igényei térben is időben változók (Nilsson-Nyström, 2013).

$\mathrm{Az}$ állami feladatok rendszerébe tartozik a képzés és az oktatás területe. A felnőttképzés vegyes finanszírozású lehet állami, egyéni vagy munkáltatói, ahol az állami szerepvállalás megközelítőleg 15-20\%. Az állami támogatás rendeltetése alapján legfőképpen a hátrányos helyzetű területeket, hátrányos helyzetüek képzését érinti és országosan kiemelt célokat és fejlesztési területeket támogat (Polónyi, 2018).

A munkanélküliek képzése és a képzési forrásai relatíve rövid ideje állnak rendelkezésre. A hátrányos helyzetü rétegek képzését négy fő forrás támogatja, a felnőttképzési normatíva, a Munkaerőpiaci Alap (MPA) foglalkoztatási alaprész, az MPA felnőttképzési célú kerete és az Európai Uniós források (GINOP). A képzések indirekt finanszírozási forrásai lehetnek az adókedvezmények, valamint a saját munkavállalók képzési támogatása (Farkas, 2014).

A hátrányos helyzetű rétegek nem szegmentálódnak a támogatás forrása szerint, hanem a hátrányos helyzetük mibenléte, koruk, iskolai végzettségük etc. alapján csoportosíthatók. A hátrányos helyzetủek múltban is részesültek támogatásban képzési programok révén, azonban országos szinten nincs differenciált képzési modell. Felnőttképzés folytató intézmények folytatnak hasonló célú képzéseket és saját képzési programokkal is rendelkeznek. A szétaprózódott képzési paletta és a felnőttképzési intézményektől függő koordinálatlan halmaza átláthatatlanná teszi a képzések hatékonyságának mérését, a kereslet és a kínálat összefüggéseit és a hátrányos helyzetű rétegek ellátása milyen mértékben elégíti ki az igényeket. Ez azért probléma, hisz ezekben az oktatásokban a legtöbb esetben az állam a megrendelő (BordásSiposné Nándori, 2019).

A hátrányos helyzetüek képzésének hatékonysága abban az esetben növelhetö, ha differenciált, tervezhető, a résztvevők igényeinek is megfelelő szakképző, felzárkóztató képzési programok kerülnek bevezetésre. Amennyiben ezek a programok részesülnek állami támogatásban, ösztönözhetik a képzésbe való részvételt és növelhetik a foglalkoztathatóságot (Polónyi, 2018).

\section{Anyag és módszer}

A szekunder kutatás megalapozásaként a témakörben elérhető hazai és nemzetközi szakkönyvek és folyóirat cikkek megismerését követően a Nemzeti Foglalkoztatási Szolgálat honlapján, valamint az OSAP 1665 Statisztikai Felületen elérhető adatbázisokat tekintettem át az ÉszakMagyarországi régió megyéinek munkanélküliségi és felnőttképzési helyzetére vonatkozóan. A régió társadalmi-gazdasági mutatóinak vizsgálata alapján annak egészére az utóbbi években a felzárkózás, az országos átlagértékektől való elmaradottság csökkenése jellemző. Az északmagyarországi megyéket ugyanakkor különbözö gazdasági és társadalmi adatok jellemzik. A megyéken belül pedig jól elkülöníthetők azok a térségek, amelyek elindultak a felzárkózás útján, azoktól, amelyek tartósan depressziós térségnek minősíthetők (Koncz et al., 2018).

A munkanélküliség szempontjából a lakónépesség számához viszonyítva Nógrád megye Borsod-Abaúj-Zemplén megyéhez hasonlóan magas mutatókkal rendelkezik a régióban, miközben a felnőttképzési részvételt vizsgálva a legalacsonyabb adatokkal rendelkezik. A régióból kimagaslik felnőttképzési mutatók szerint Borsod-Abaúj-Zemplén megye. Az Európai Unió által támogatott képzéseket tekintve, amelyek az álláskeresőknek szóló integrációjára hivatottak, Nógrád és Heves megyék nem csak a régióban, hanem az országos adatokat vizsgálva is kedvezőtlen adatokkal rendelkeznek. A munkanélkülieknek szóló képzések célja, hogy a megszerzett új végzettséggel sikeresen vissza tudjanak integrálódni a munkaerő-piacra. Az 
összegyüjtött adatbázis feldolgozását, kiértékelését a Microsoft Office 2013 és IBM SPSS Statistics 20 programok segítségével végeztem el.

\section{Eredmények}

Az Észak-Magyarországi régió munkanélküliségi mutatói évtizedek óta magasabbak az országos átlagnál. A 2019. évi adatok alapján a második helyen áll az álláskeresők relatív számát tekintve, aminél csak az Észak-Alföldi régió rendelkezik rosszabb mutatókkal. Megyei szinten vizsgálva a legmagasabb munkanélküliségi adatokkal Borsod-Abaúj-Zemplén megye rendelkezett 2019-ben, ami annak is köszönhető, hogy Nógrád megyében jelentősebb csökkenés valósult meg az utolsó két évben (1. táblázat).

1. táblázat: A nyilvántartott álláskeresők gazdaságilag aktív népességhez viszonyított relatív mutatója az Észak-Magyarországi régió megyéiben

\begin{tabular}{|l|c|c|c|c|c|}
\hline \multicolumn{1}{|c|}{ Terület } & $\mathbf{2 0 1 5}$ & $\mathbf{2 0 1 6}$ & $\mathbf{2 0 1 7}$ & $\mathbf{2 0 1 8}$ & $\mathbf{2 0 1 9}$ \\
\hline Észak-Magyarországi régió & 15,4 & 11,8 & 12,2 & 11,2 & 11,2 \\
\hline Borsod-Abaúj-Zemplén megye & 16,6 & 11,6 & 13,2 & 12,3 & 12,5 \\
\hline Heves megye & 11,5 & 10,3 & 9,0 & 8,0 & 8,1 \\
\hline Nógrád megye & 17,4 & 13,0 & 13,9 & 12,5 & 11,9 \\
\hline
\end{tabular}

Forrás: Saját készítés (www.nfsz.munka.hu) alapján

A gazdaságilag aktív népességhez viszonyított nyilvántartott álláskeresők relatív mutatója szerint, Borsod-Abaúj-Zemplén megye rendelkezik a legrosszabb mutatóval, majd Nógrád megye követi a legjobb helyzetben Heves megye van, amely az országos adatokat tekintve nem kimagasló.

Az egy före jutó bruttó hazai össztermék (GDP) alapján Heves megye rendelkezik a legnagyobb gazdasági teljesítménnyel és a vizsgált időszakban ez a megye fejlődött a legnagyobb arányban. Nógrád megye mind a bruttó hazai össztermék, mind a vizsgált időszakban mutatott fejlődési arány szempontjából a legrosszabb helyen áll az Észak-Magyarországi régióban. Az álláskeresők számának csökkenése mellett a gazdasági teljesítmény bővült ugyan, azonban a lemaradás mértéke ma is óriási (2. táblázat).

2. táblázat: Az egy före jutó GDP az Észak-Magyarországi régió megyéiben

\begin{tabular}{|l|r|r|r|r|}
\hline \multicolumn{1}{|c|}{ Megye } & \multicolumn{1}{c|}{$\mathbf{2 0 1 5}$} & \multicolumn{1}{c|}{$\mathbf{2 0 1 6}$} & \multicolumn{1}{c|}{$\mathbf{2 0 1 7}$} & \multicolumn{1}{c|}{$\mathbf{2 0 1 8}$} \\
\hline Borsod-Abaúj-Zemplén megye & 14280 & 13909 & 15367 & 16122 \\
\hline Heves megye & 14341 & 14519 & 15031 & 16342 \\
\hline Nógrád megye & 8900 & 8669 & 9136 & 9734 \\
\hline
\end{tabular}

Forrás: Saját készítés (www.ksh.hu) alapján

A felnőttképzési formában bejelentett tanfolyamokat tekintve Borsod-Abaúj-Zemplén megye kimagaslik az Észak-Magyarországi régióból, több képzéssel rendelkezik, mint a régióban található másik két megye együttesen. A képzések számából adódóan a résztvevők száma is ebben a megyében a legmagasabb. Borsod-Abaúj-Zemplén megyében az Európai Unió által támogatott álláskeresőknek szóló képzések sokasága miatt magas a képzések száma (3. táblázat).

3. táblázat: A képzések (tanfolyamok) száma megyénként

\begin{tabular}{|c|c|c|c|c|c|c|}
\hline Megye & 2015 & 2016 & 2017 & 2018 & 2019 & Összesen \\
\hline
\end{tabular}




\begin{tabular}{|l|r|r|r|r|r|r|} 
Borsod-Abaúj-Zemplén megye & 3752 & 2349 & 4478 & 5665 & 5272 & 21516 \\
\hline Heves megye & 1754 & 1394 & 1695 & 1858 & 2231 & 8932 \\
\hline Nógrád megye & 679 & 296 & 560 & 940 & 1505 & 3980 \\
\hline
\end{tabular}

Forrás: Saját készítés (www.osap.mer.gov.hu) alapján

Országos összehasonlításban a felnőttképzéssel foglalkozó intézmények darabszáma alapján az Észak-Magyarországi régió a negyedik helyen áll, természetesen Budapest (738) kimagaslik az országos adatokból. Borsod-Abaúj-Zemplén megyében található a régió legtöbb (69 db) felnőttképzéssel foglalkozó intézménye. A másik két megyében (Heves $30 \mathrm{db}$, Nógrád 23db) összesen nincs annyi intézmény, mint Borsod-Abaúj-Zemplén megyében. A képzési intézmények száma is jól tükrözi, hogy mely megyékben milyen mértékben vannak jelen a támogatott képzések.

$\mathrm{Az}$ Észak-Magyarországi régió nem rendelkezik jó gazdasági mutatókkal, ennek következtében a költségtérítéses, iskolarendszeren kívüli felnőttképzésre nincs akkor kereslet, mint az ország nyugati részein. A felnőttképzéssel foglalkozó intézmények legbiztosabb megélhetési forrása az Európai Unió által támogatott álláskeresőknek szóló képzések.

A költségviselők szerinti eloszlásban a legrosszabb gazdasági mutatókkal rendelkező Nógrád megyében a legnagyobb arányban $(21,05 \%)$ vesznek részt képzéseken saját költségein a résztvevők, Heves megyében 16,53\%, míg Borsod-Abaúj-Zemplén megyében 10,92\%. BorsodAbaúj-Zemplén megyében a támogatottság mértéke következtében nem vesznek részt költségtérítéses formában a tanuló vágyó felnőttek. Heves megyében és Nógrád megyében a résztvevők száma nagyon alacsony az ország többi megyéihez képest is.

A 4. táblázatban is megfigyelhető, hogy csak Heves megyében vett részt több férfi felnőttképzésben, ami nagyon ritka, hisz általánosságban elmondható, hogy minden egyes területen az országban mindenhol a nök voltak többségben.

4. táblázat: Az Észak-Magyarországi régióban található megyék költségviselői eloszlása nemenként (2019)

\begin{tabular}{|l|r|r|r|r|r|r|}
\hline \multirow{2}{*}{ Költségviselök } & \multicolumn{2}{c|}{$\begin{array}{c}\text { Borsod-Abaúj- } \\
\text { Zemplén }\end{array}$} & \multicolumn{2}{c|}{ Heves } & \multicolumn{2}{c|}{ Nógrád } \\
\cline { 2 - 7 } & \multicolumn{1}{|c|}{ férfi } & \multicolumn{1}{c|}{ nő } & \multicolumn{1}{c|}{ férfi } & \multicolumn{1}{c|}{ nő } & \multicolumn{1}{c|}{ férfi } & nő \\
\hline $\begin{array}{l}\text { A képzésbe beiratkozott természetes } \\
\text { személy }\end{array}$ & 3733 & 3622 & 2154 & 1887 & 3062 & 507 \\
\hline Egyéb & 919 & 254 & 107 & 130 & 20 & 65 \\
\hline Egyéb nemzetközi forrás & 38 & 13 & 0 & 0 & 0 & 0 \\
\hline Európai Uniós forrás & 16914 & 25697 & 3583 & 6294 & 3964 & 7481 \\
\hline Nemzeti Foglalkoztatási Alap & 482 & 235 & 955 & 383 & 75 & 26 \\
\hline $\begin{array}{l}\text { Nemzeti Foglalkoztatási Alapon } \\
\text { kívüli központi költségvetési forrás }\end{array}$ & 11 & 93 & 16 & 46 & 0 & 18 \\
\hline Szakképzési hozzájárulás & 361 & 123 & 173 & 57 & 3 & 2 \\
\hline $\begin{array}{l}\text { Vállalkozások és költségvetési } \\
\text { szervezetek nem a szakképzési } \\
\text { hozzájárulás terhére, illetve non- } \\
\text { profit szervezetek (munkáltatóként) }\end{array}$ & 9882 & 4953 & 6581 & 2077 & 1289 & 441 \\
\hline Összesen & $\mathbf{3 2 3 4 0}$ & $\mathbf{3 4 9 9 0}$ & $\mathbf{1 3 5 6 9}$ & $\mathbf{1 0 8 7 4}$ & $\mathbf{8 4 1 3}$ & $\mathbf{8 5 4 0}$ \\
\hline
\end{tabular}

Forrás: Saját készítés (www.osap.mer.gov.hu) alapján 
A régió megyéiben a lemorzsolódási arány nem kirívó egyik megyében sem. A legnagyobb mértékü lemorzsolódás 2015-ban Borsod-Abaúj-Zemplén megyében volt és összességében is ez a megye rendelkezik a legrosszabb arányokkal. Heves megyében és Nógrád megyében folyamatosan csökken a lemorzsolódási arány, ami a magas saját költségtérítéses formának köszönhető (5. táblázat).

5. táblázat: Lemorzsolódási arány az Észak-Magyarországi régió megyéiben

\begin{tabular}{|l|r|r|r|r|r|}
\hline \multicolumn{1}{|c|}{ Megye } & $\mathbf{2 0 1 5}$ & \multicolumn{1}{c|}{$\mathbf{2 0 1 6}$} & \multicolumn{1}{c|}{$\mathbf{2 0 1 7}$} & \multicolumn{1}{c|}{$\mathbf{2 0 1 8}$} & \multicolumn{1}{c|}{$\mathbf{2 0 1 9}$} \\
\hline Borsod-Abaúj-Zemplén & $3,74 \%$ & $2,47 \%$ & $2,34 \%$ & $2,36 \%$ & $1,48 \%$ \\
\hline Heves & $2,51 \%$ & $1,32 \%$ & $1,56 \%$ & $1,28 \%$ & $1,13 \%$ \\
\hline Nógrád & $0,28 \%$ & $3,71 \%$ & $2 \%$ & $2,61 \%$ & $1,46 \%$ \\
\hline
\end{tabular}

Forrás: Saját készítés (www.osap.mer.gov.hu) alapján

Munkaerő-piaci szempontból az Országos Képzési Jegyzékben szereplő szakmák a leglényegesebbek, hisz egy új szakmai végzettséggel könnyebben tud elhelyezkedni, újra a munkavilágába visszakerülni az álláskereső, mint egy nem szakmai képzéssel, esetleg egy tréninggel. A tréningeknek is lehet munkaerö-piaci szerepe, azonban munkahely megtartó képessége nincs. A tréningek számos olyan kompetenciát fejleszthetnek, melyeket nem csak a munkaerőpiacon hasznosíthatnak a résztvevők, hanem a mindennapokban is (6. táblázat).

6. táblázat: Országos Képzési Jegyzékben szereplö szakmai képzésekben résztvevök száma az Észak-Magyarországi régió megyéiben

\begin{tabular}{|c|c|c|c|c|c|c|}
\hline Képzés helyszíne (megye) & 2015 & 2016 & 2017 & 2018 & 2019 & Összesen \\
\hline Borsod-Abaúj-Zemplén megye & 10922 & 7174 & 13302 & 14267 & 11094 & 56759 \\
\hline Heves megye & 4145 & 3732 & 3722 & 4793 & 5398 & 21790 \\
\hline Nógrád megye & 2440 & 1416 & 2145 & 2849 & 2631 & 11481 \\
\hline
\end{tabular}

Forrás: Saját készítés (www.osap.mer.gov.hu) alapján

Az Észak-Magyarországi régióból szembetűnően kimagaslik Borsod-Abaúj-Zemplén megye az OKJ-s képzéseken résztvevők számát tekintve. Az álláskeresők számát a gazdaságilag aktív népességhez viszonyítva Nógrád megye majdnem megegyezik Borsod-Abaúj-Zemplén megye adataival, mégis Nógrád megyében a képzések-, a képzéseken résztvevők számát tekintve az országos adatokat tekintve a legrosszabb statisztikai mutatókkal rendelkezik, azonban az Európai Unió által támogatott álláskeresőknek szóló képzések nincsenek preferálva, ennek következtében a nyilvántartott álláskeresők száma nem képes az elvárt módon csökkeni.

Az Észak-Magyarországi régióban az Európai Unió által támogatott Országos Képzési Jegyzékben szereplő szakmai képzéseken résztvevők szám a vizsgált 4 évben növekvő tendenciát mutat, minden megyében. Az 1. ábrán is jól látható, hogy Borsod-Abaúj-Zemplén megye rendelkezik a legnagyobb támogatási aránnyal. Az Európai Unió által támogatott Országos Képzési Jegyzékben szereplő szakmai képzéseken résztevők (nyilvántartott álláskeresők) számát tekintve több mint negyede részt vett támogatott szakmai képzésen Borsod-Abaúj-Zemplén megyében. Nógrád megyében majdnem megegyezik a támogatott képzéseken résztvevői arány Heves megyével, azonban Nógrád megye sokkal rosszabb gazdasági mutatókkal rendelkezik. 


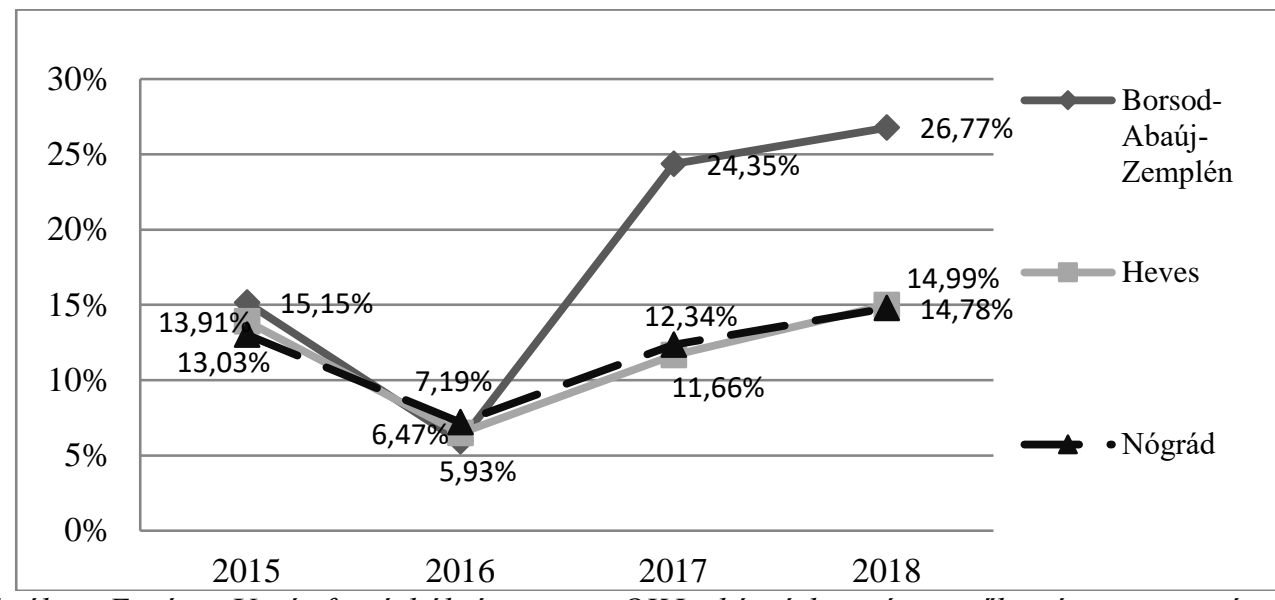

1. ábra: Európai Uniós forrásból támogatott OKJ-s képzésben résztvevők aránya viszonyitva a nyilvántartott álláskeresők számához

Forrás: Saját készítés (www.osap.mer.gov.hu és www.nfsz.munka.hu) alapján

A régió megyéi közül Borsod-Abaúj-Zemplén megye kétszer több támogatott létszámmal rendelkezik, mint a másik két megye összesen. Az Európai Unió sokkal több tréninget, kompetencia fejlesztést és összességében általános felnőttképzést támogat, mint szakmai képzéseket. Ebből adódóan az álláskeresőknek szóló képzések tekintetében nem érik el a kívánt hatást a képzések, hisz nem tudnak elhelyezkedni vele a résztvevők. Sokkal inkább szakmai képzéseket kellene a támogatónak előnyben részesítenie, hogy a munkaerőpiacon felmerült betöltetlen álláshelyek betöltötté váljanak (7. táblázat).

7. táblázat: Európai Uniós forrásból támogatott összes iskolarendszeren kívüli képzés az ÉszakMagyarországi régióban

\begin{tabular}{|l|r|r|r|r|r|}
\hline \multicolumn{1}{|c|}{ Megye } & \multicolumn{1}{c|}{$\mathbf{2 0 1 5}$} & \multicolumn{1}{c|}{$\mathbf{2 0 1 6}$} & \multicolumn{1}{c|}{$\mathbf{2 0 1 7}$} & \multicolumn{1}{c|}{$\mathbf{2 0 1 8}$} & \multicolumn{1}{c|}{$\mathbf{2 0 1 9}$} \\
\hline Borsod-Abaúj-Zemplén & 34020 & 5328 & 38912 & 53425 & 42611 \\
\hline Heves & 8492 & 1465 & 6546 & 6430 & 9877 \\
\hline Nógrád & 5747 & 1342 & 4942 & 7283 & 11445 \\
\hline
\end{tabular}

Forrás: Saját készítés (www.osap.mer.gov.hu) alapján

A támogatott képzési paletta kialakítása az országos helyzetkép alapján történik, és csak kevéssé veszi figyelembe helyi igényeket. A támogatott hiányszakmák között vannak olyan képzések, amelyekre a Borsod-Abaúj-Zemplén Kormányhivatal 8 éve nem tudott egy álláskereső csoportot összedelegálni (mechatronikai technikus). Számos esetben a képzések megnevezése okoz gondot a toborzás során, mivel azokat a jelentkezők nem tudják beazonosítani, nem tudják, hogy mivel is foglalkoznak a szakmát elvégzők. Véleményem szerint a helyi gazdasági struktúrát figyelembe véve kellene megállapítani, hogy milyen képzettekre van szüksége a helyi gazdaságnak, a helyi vállalkozóknak. A Szociális gondozó és ápoló képzés hatalmas sikernek örvendett az elmúlt hat évben, a végzettek közel fele el tudott helyezkedni az új végzettséggel.

Számos szakmai végzettséggel be lehetne tölteni a helyi piaci ürt, ilyen képzések a hegesztő, a lakatos, a festő a kőműves, az ács, azaz a kétkezi szakmák, azonban elmondható, hogy manapság a fiatalok nem szeretnének ezeken a területeken továbbtanulni. Mindeközben azon kevesek, akik ezeket a szakmákat tanulták, el tudtak helyezkedni a regionális munkaerőpiacon is. Ugyanakkor további, igen jelentős problémaként kell megnevezni az elvándorlást, ugyanis a végzettek egy része Budapestre, a Nyugati országrészbe, a legtöbben pedig külföldre mennek munkát vállalni. 


\section{Összefoglalás}

Az Észak-Magyarországi régió minden gazdasági-társadalmi mutatót tekintve a legrosszabbak között van az országban, igaz, az utóbbi évtized kedvező tendenciáinak köszönhetően elmozdult a legutolsó helyről. A felnőttképzési statisztikákat tekintve Borsod-Abaúj-Zemplén megye az ország második legjobb statisztikai adataival rendelkezik az iskolarendszeren kívüli képzéseket tekintve, mind résztvevői, mind támogatottsági szempontból.

Az Észak-Magyarországi régió évtizedek óta magas munkanélküliséggel küzdő régió, az itt található megyék közül Borsod-Abaúj-Zemplén és Nógrád megye rendelkezik a legnagyobb munkanélküliséggel a régióban. Amíg Borsod-Abaúj-Zemplén megyében kimagasló számban szerveznek felnőttképzéseket, addig Nógrád megyében nagyon csekély a támogatott képzések száma. Ez összefüggésbe hozható az utóbbi megye szolgáltatócentrumainak gyengeségével és eltérö térszerkezeti pozíciójával (Budapest közelsége).

Munkaerő-piaci szempontból az Országos Képzési Jegyzékben szereplő szakmai képzéseket kellene támogatnia az Európai Uniónak és a képzéseket is a vidéki térségekre, járások központjaiba kellene indítani, hisz ezzel munkaerő megtartó képességét növeli a térségnek. A helyben képződnek és a helyi vállalkozóknál vesznek részt gyakorlati oktatásban és megfelelőnek találják a munkáltatók a képzésen résztvevőket, még munkát is ajánlhatnának nekik, amelynek következtében a térségben maradnának, így csökkenne az elvándorlás mértéke.

Nógrád megyében a legmagasabb a költségtérítéses formában tanulók aránya, ennek következtében kijelenthető, hogy a megyében magas a tanulási akarat. Több Európai Unió által támogatott iskolarendszeren kívüli képzést kellene a megyében indítani, ezzel is növelve a résztvevők számát, ezzel tovább lehetne csökkenteni az álláskeresők számát.

Heves megyében a támogatott képzések száma elegendőnek bizonyulnak a nyilvántartott álláskeresők számához képest, azonban magasabb támogatói részvétel mellett tovább csökkenthető lenne az álláskeresők száma.

\section{Irodalomjegyzék}

ALPEK B. L. - TÉSITS R. (2014): A munkaerőpiaci szenzitivitás. Területi Statisztika 54(4), pp. 333-359.

BORDÁS G. - SIPOSNÉ NÁNDORI E. (2019): A munka világába történő integrációt segítő képzések: marginális munkaerőpiaci rétegek, képzések és átképzések a Miskolci Járásban. = Észak-magyarországi Stratégiai Füzetek 19(3), pp. 69-75

BÓDI F. - OBÁDOVICS CS. (2000): Munkanélküliség a vidéki Magyarországon. Területi Statisztika 40(1), pp. 55-68.

CEDEFOP (2015): Job-related adult learning and continuing vocational training in Europe: a statistical picture.Luxembourg: Publications Office. Cedefop research paper; No 48. http://dx.doi.org/10.2801/392276

CSERNÉ ADERMANN G. - FODOR I. - KOLTAI D. (2006): A felnőttek foglalkoztathatóságának növelésére irányuló komplex képzési modellek, különös tekintettel a hátrányos helyzetü csoportokra, javaslatok intézkedésekre. Kutatási zárótanulmány, $236 \mathrm{p}$.

FARKAS É. (2014): A felnőttképzés finanszírozása: hazai folyamatok, nemzetközi trendek. In: Henczi L. (szerk.) A szak- és felnőttképzés-szervezés gyakorlata. Budapest, RAABE Tanácsadó és Kiadó Kft., pp. 1-37.

FARKAS É. (2016): A felnőttképzés jogi szabályozása, minőségbiztosítása, finanszírozása Magyarországon. Kézirat. Háttértanulmány az Oktatási Hivatal megbízásából.

GYŐRI T. - EGRI Z. (2020): A munkanélküliek - mint potenciális munkaerő-tartalék térszerkezetének vizsgálata Békés megyében. Studia Mundi Economica 7(2), pp. 2-17.

KÁPOSZTA J. - TÓTH T. (2014): Regionális és vidékfejlesztési ismeretek. Gödöllő, Szent István Egyetemi Kiadó. 168 p. ISBN 978-963-269-402-3 
KISPÁLNÉ HORVÁTH M. (2015): A felnőttképzés hatékony módszertana a tanulói elvárások tükrében. In: Kispálné Horváth Mária (szerk.) Módszertani irányok a pedagógusképzés fejlesztésében Nyugat-Dunántúlon. Szombathely, Nyugat-magyarországi Egyetem Regionális Pedagógiai Szolgáltató és Kutató Központ, pp. 39-50.

KONCZ G. - SZÜCS A. - NAGYNÉ DEMETER D. (2018): A gazdaság térszerkezetének változásai Észak-Magyarországon az ezredforduló után. = Jelenkori Társadalmi és Gazdasági Folyamatok 13(1-2), pp. 139-149.

LIVINGSTONE, D. W. (2010). Job requirements and workers' learning: formal gaps, informal closure, systemic limits. Journal of Education and Work 23(3), pp. 207-231. doi: $10.1080 / 13639081003785732$

NIJHOF, W. J. (2005). Lifelong learning as a European skill formation policy. Human resource development review 4(4), pp. 401-417.

NILSSON, S. (2010b). On the Meaning of Higher Education in Professional Practice: the case of physicians and engineers. Journal of Education and Work 23(3), pp. 255-274. doi: 10.1080/13639080.2010.486397

NILSSON, S. - NYSTRÖM, S. (2013): Adult learning, education, and the labour market in the employability regime. European Journal for Research on the Education and Learning of Adults 4(2), pp. 171-187. DOI 10.3384/rela.2000-7426.rela9007

POLÓNYI I. (2018): A felnőttképzés megtérülései. In: Fodorné, Tóth Krisztina (szerk.) A felsőoktatási lifelong learning társadalmi és gazdasági haszna: kutatás - fejlesztés innováció. Debrecen, MELLearN Felsőoktatási Hálózat az életen át tartó tanulásért Egyesület, pp. 99-113.

SIPOSNÉ NÁNDORI E. (2016): A munkaerőpiaci hátrányok területi vonatkozásai ÉszakMagyarországon. Területi Statisztika 56(4), pp. 438-454. 